\title{
Exploitation of phytoplankton as a food resource by the kelp bed ascidian Pyura stolonifera
}

\author{
L. J. Seiderer ${ }^{1}$, R. C. Newell ${ }^{2}$ \\ 'Marine Biology Research Institute, University of Cape Town, Rondebosch 7700, South Africa \\ ${ }^{2}$ Marine Ecological Surveys Ltd, PO Box 6, Faversham, Kent ME13 8AA, United Kingdom
}

\begin{abstract}
The ascidian Pyura stolonifera (Heller) is an important component of the filter-feeding community off the coast of South Africa. Scanning electron microscopy of the inhalant siphon, pharyngeal basket and gut contents of freshly-collected ascidians suggests that the food supply comprises a mixed resource of phytoplankton cells of 3 to $5 \mu \mathrm{m}$ diameter, particulate detritus and diatoms. There is a progressive concentration of cells of 3 to $5 \mu \mathrm{m}$ diameter during passage through the pharynx, and these form a dominant component of the material taken into, and lysed in the gut. Some diatoms and detritus are also ingested, but to a large extent pass through the gut undigested. Digestive enzyme activity in the endostyle was negligible, but protease, chitinase, laminarinase and $\alpha$-amylase were of importance in the gut. Very little cellulase activity occurred in the gut, and there was no evidence of significant bacterial involvement in the decomposition of complex polysaccharides. This indicates that phytoplankton is likely to be of more significance in the diet of $P$. stolonifera than the refractory components in the water column. The relatively high specific activity of carbohydrases in the gut results in a large energetic gain relative to estimated carbon losses through respiration. $P$. stolonifera thus appears to be well-adapted to exploit the episodic phytoplankton availability which characterises the southern Benguela upwelling system, and in this respect resembles the mussel Choromytilus meridionalis which, together with $P$. stolonifera, forms the major suspension-feeding component in the kelp beds off the west coast of the Cape Peninsula. It therefore seems likely that the particulate matter which dominates the water column in kelp beds enters the decomposer pathway and does not represent a nutritional resource which is exploited directly by the filter-feeding community.
\end{abstract}

\section{INTRODUCTION}

Kelp bed communities off the west coast of the Cape Peninsula, South Africa, have been described in detail by Field et al. $(1977,1980)$ and by Velimirov et al. (1977). They showed that the filter-feeding component is dominated by mussels (mainly Aulacomya ater and Choromytilus meridionalis), sponges (Haliclona anonyma) and the large ascidian Pyura stolonifera. Subsequent work showed that particulate and dissolved matter produced from kelp fragmentation enters the microbial food web (Stuart et al. 1981, Newell \& Field $1983 \mathrm{a}$, b) and is also 'exported' into adjacent nearshore systems under upwelling conditions (Field et al. 1977, Koop et al. 1982, Wulff \& Field 1983).

The filter-feeders themselves show some evidence of 'partitioning' of the suspended food resources on a particle size basis. Stuart \& Klumpp (1984) found that 3 species of mussels retained particles of $>4 \mu \mathrm{m}$ diameter with $100 \%$ efficiency, but that retention efficiency fell to only $20 \%$ for particles of $0.6 \mu \mathrm{m}$ diameter. Sponges, however, showed the highest retention efficiency for small particles of $0.6 \mu \mathrm{m}$ and a declining efficiency for large particles. Finally, the ascidian Pyura stolonifera retained all particles $>0.6 \mu \mathrm{m}$ with an efficiency of almost $100 \%$, suggesting that this component of the filter-feeding community was capable of exploiting the entire spectrum of particulate matter available as a potential food resource in the water column. Suspensions of natural particulate material from the kelp bed were absorbed with an efficiency of $34 \%$ by $P$. stolonifera and it has been estimated that at natural seston concentrations the ascidian could cover maintenance energy costs and have ca $27 \%$ of assimilated energy available for growth and reproduction (Klumpp 1984).

In some cases, the microflora of the gut may play a role in the degradation of refractory components of the diet, including seston derived from macrophyte fragmentation. Fong \& Mann (1980) showed that the gut microflora of a sea urchin, Strongylocentrotus 
droebachiensis, was capable of uptake of ${ }^{14} \mathrm{C}$-labelled glucose, and that the label from bacterial protein was subsequently incorporated into the tissues of the urchin. Mann (1982) also cites results of work in which ${ }^{14} \mathrm{C}$-label in cellulose was incorporated into bacterial protein and subsequently appeared in the proteins of the urchins (see also Lasker \& Giese 1954, Prim \& Lawrence 1975). Similarly Wainwright \& Mann (1982) showed that bacteria in the gut of the mysid shrimp Mysis stenolepis were capable of cellulose degradation and may thus play a role in the digestion of refractory components of the diet of this animal. It has also been known for many years that gut bacteria are of importance in the degradation of cellulose and in fixation of nitrogen by the wood-boring bivalve Teredo navalis (Hidaka 1953, Carpenter \& Culliney 1975, Morita 1980). More recently, Prieur $(1981,1982$; see also Seiderer et al. 1987) has suggested that digestion of resident bacteria in the gut may also be of significance in the nutrition of a variety of other bivalves.

As far as we are aware, there is no detailed information on the precise nature of the food exploited by Pyura stolonifera under natural conditions, whether a microflora occurs in the gut, nor whether micro-organisms contribute to the digestion of natural seston filtered from the water column by this important component of the filter-feeding community of kelp beds. The following work was therefore undertaken to determine the nature of the food resource utilised by $P$. stolonifera, to characterise the gut microflora of this ascidian and to determine the relative significance of host enzymes and those of the gut microflora in carbon assimilation.

\section{MATERIALS AND METHODS}

Nature of gut contents and endostyle microflora. Specimens of the ascidian Pyura stolonifera (Heller) were collected from Oudekraal on the west coast of the Cape Peninsula, South Africa, by removing entire individuals, including test, from the rocks. They were transported to the laboratory on ice, where they were dissected into inhalant siphon, endostyle, pharyngeal basket, stomach plus contents and hindgut plus contents. These were fixed in $2.5 \%$ glutaraldehyde in phosphate buffer $(\mathrm{pH} 7.2)$ for $48 \mathrm{~h}$ at $4{ }^{\circ} \mathrm{C}$. Samples were rinsed in 3 changes of phosphate buffer and left in buffer overnight. The material was then passed through a standard graded alcohol dehydration series from $50 \%$ to pure ethanol, and subsequently dried in a Polaron critical point dryer for $3.5 \mathrm{~h}$ using liquid $\mathrm{CO}_{2}$ as the transitional fluid. Samples were mounted on a stub using glue and carbon graphite, and coated with gold palladium for 6 min at $4 \mathrm{~V}$. Viewing was carried out in a Cambridge $\mathrm{S} 200$ series Scanning Electron Microscope.

Enzyme activities. Collection of material. Thirteen individuals were collected from Oudekraal and immediately dissected in the laboratory. The gut volume of 6 of the ascidians was estimated by measuring the gut bore $(\overline{\mathrm{X}}=3.3 \mathrm{~mm} \pm 0.52 \mathrm{SD})$ and length $(\overline{\mathrm{X}}=$ $51 \mathrm{~mm} \pm 14.3 \mathrm{SD})$. The mean gut volume of the 6 ascidians was $0.276 \mathrm{ml}$ ( $\pm 0.122 \mathrm{SD}$ ) and the mean dry tissue weight of the specimens was $2.65 \mathrm{~g}$ ( $\pm 0.82 \mathrm{SD}$ ). In order to estimate the protein content of the entire gut, samples of gut contents were removed from the 6 experimental specimens, pooled and homogenised with a glass tissue grinder in $67 \mathrm{mM}$ phosphate buffer $\mathrm{pH} 7.0$ with $150 \mathrm{mM} \mathrm{NaCl}$, centrifuged at $12000 \times \mathrm{g}$ for $2 \mathrm{~min}$, and the supernatant decanted for assay of protein by the method of Lowry et al. (1951).

A further 7 individuals were dissected into endostyle and gut contents. These were pooled, homogenised and centrifuged as before and the supernatants decanted for subsequent enzyme assays. Both the endostyle and gut content supernatants were halved, one half being treated with phenylmethylsulfonyl fluoride (PMSF) to inhibit protease activity. Treatment with PMSF resulted in complete inhibition of protease activity as expected. In all other assays the difference between PMSF-treated extracts and untreated extracts was negligible. Protease inhibitor was therefore not used in subsequent enzyme assays.

All enzyme assays were performed in triplicate, at varying incubation times indicated in Table 1. Protein content was assayed by the method of Lowry et al. (1951) and enzyme activities expressed per mg protein of crude homogenate.

Enzyme assays. Carbohydrase. Laminarinase was assayed by the method of Jacober et al. (1980) using a substrate of $0.4 \%$ laminarin (Sigma). Aliquots of $250 \mu \mathrm{l}$ enzyme extract which had been suitably diluted with phosphate buffer were added to an equal volume of laminarin and incubated in a shaking water bath at $24^{\circ} \mathrm{C}$ for 0,10 and $30 \mathrm{~min}$. Three replicate tubes were used at each time interval and for each extract. Reducing sugars were measured at $660 \mathrm{~nm}$ using the Nelson-Somogyi method (Nelson 1952). Absorbance values were converted to maltose equivalents using the regression.

$$
y=0.07+8.56 \times\left(n=10, r^{2}=1.00\right)
$$

where $y=$ absorbance at $660 \mathrm{~nm} ; x=\mathrm{mg}$ maltose

The enzyme $\alpha$-amylase was also assayed by the Nelson-Somogyi method using $0.5 \%$ oyster glycogen (Merck) as a substrate. Cellulase was assayed in the same way using $0.1 \%$ carboxymethyl cellulose (CMC; $\mathrm{BDH}$ chemicals) as a substrate 
Chitinase. Chitin substrate was prepared by the method of Reichenbach \& Dworkin (1981). Ten g powdered crab shell chitin (Sigma) was treated with $100 \mathrm{ml}$ cold concentrated $\mathrm{HCl}$ for $1 \mathrm{~h}$. The chitin was then precipitated by pouring the solution into 11 distilled water at $4{ }^{\circ} \mathrm{C}$ whilst stirring vigorously. The precipitate was collected by filtration onto a fibreglass filter (Whatman $G F / C$ ) and dialysed overnight against running tap water. The $\mathrm{pH}$ was then adjusted to 7.0 with $1 \mathrm{NKOH}$ and the resultant slurry was autoclaved without allowing complete drying.

Aliquots of $250 \mu \mathrm{l}$ of enzyme preparation were added to an equal volume of the chitin slurry $\left(20.3 \mathrm{mg} \mathrm{ml}^{-1}\right.$ dry weight) plus $50 \mu$ toluene to inhibit bacterial activity (Okutani 1966) and the mixture incubated in a shaking bath for 0,48 and $120 \mathrm{~h}$ at $24^{\circ} \mathrm{C}$. Three replicate samples were taken at each time interval and were assayed for the chitinase endproduct $\beta-1,4$ linked $N$ acetylglucosamine (NAG) according to the method or Reissig et al. (1955; see also Monreal \& Reese 1969) using a wavelength of $585 \mathrm{~nm}$.

Chitinolytic activity was expressed as $\mathrm{mg}$ NAG (Sigma) from the calibration equation:

$$
y=0.06+30.55 \times\left(n=11, r^{2}=0.99\right)
$$

where $y=$ absorbance at $585 \mathrm{~nm} ; x=\mathrm{mg}$ NAG.

Protease. Azocasein (Sigma) (for substrate suitability, see Reimerdes \& Klostermeyer 1976) was made

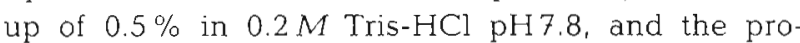
tease assayed after the method of Long et al. (1981). Then $250 \mu \mathrm{l}$ enzyme was added to $500 \mu \mathrm{l}$ of azocasein substrate and incubated in a shaking water bath at $24^{\circ} \mathrm{C}$ for 0,30 and $60 \mathrm{~min}$. The reaction was stopped by the addition of $1 \mathrm{ml} 10 \%$ trichloracetic acid and the vials were held at $5{ }^{\circ} \mathrm{C}$ for $30 \mathrm{~min}$. The precipitate was then sedimented by centrifugation, and $1 \mathrm{ml}$ of the supernatant added to $1 \mathrm{ml} 1 \mathrm{~N} \mathrm{NaOH}$. The acidsoluble azopeptides were determined spectrophotometrically at $440 \mathrm{~nm}$ and the results expressed in terms of the equivalent commercial proteinase-K (Merck) activity.

Uptake of substrates by bacteria. Inhalant siphon, endostyle, gut contents and faeces were dissected from 5 freshly-collected Pyura stolonifera and homogenised separately over ice in sterile $0.2 \mu \mathrm{m}$ filtered seawater. Samples of $100 \mu l$ homogenate were then removed with a sterile pipette, spread on seawater agar plates (Seiderer et al. 1984) and incubated at $24^{\circ} \mathrm{C}$ for $72 \mathrm{~h}$. Isolates were restreaked until pure cultures were obtained. Eight isolates from the endostyle, which appeared to be almost a monoculture, were used in subsequent assays. Two cultures were also isolated from the inhalant siphon, 4 from the gut contents and 1 from the faeces.

\section{RESULTS}

\section{Structure and contents of the gut}

Although the structure of the pharyngeal basket and the nature of the feeding mechanism in ascidians is well known (Barnes 1974) there is some doubt whether selection of food particles occurs, and about the sites where rejection takes place (Millar 1960, Klumpp 1984).

A series of scanning electron micrographs of the pharyngeal basket of Pyura stolonifera which had been freshly-collected from the subtidal zone at Oudekraal on the west coast of the Cape peninsula is shown in Fig. 1. Fig. 1A shows the mixed resource of rounded cells resembling dinoflagellates and the detrital material which comprised the food supply at the inhalant siphon. Fig. 1B, C show successive enlargements of the pharyngeal basket region, including the complex ciliation surrounding the pharyngeal slits. Fig. 1D to $F$ show details of the cells of 3 to $5 \mu \mathrm{m}$ diameter which had apparently been differentially selected during passage through the pharynx, and which formed a dominant component of the material entering the gut.

Fig. 2A, B shows details of the endostyle and the coccoid cells which are associated with the mucilage strands in this region. Fig $2 \mathrm{C}, \mathrm{D}$ shows that the dominant component of the food supply which entered the gut comprised the 3 to $5 \mu \mathrm{m}$ diameter cells which were lysed during passage through the gut. Fig. $2 \mathrm{E}$ shows a diatom cell in the hind gut showing little evidence of digestion while Fig. $2 \mathrm{~F}$ shows the diatom frustules and other refractory material which comprises the faeces.

These observations on freshly-collected Pyura stolonifera thus suggest that the food supply at the inhalant siphon comprises a mixed resource of phytoplankton cells of 3 to $5 \mu \mathrm{m}$ diameter, particulate detritus and diatoms. There appears to be a progressive concentration of cells of 3 to $5 \mu \mathrm{m}$ during passage through the pharynx and which form a dominant component of the material taken into and lysed in the mid-gut. Some detritus and diatoms are also evidently ingested, but to a large extent appear to pass through the gut undigested.

\section{Digestive enzymes of Pyura stolonifera}

Carbohydrase activity in a wide variety of invertebrates has been studied by Kristensen (1972) and Elyakova et al. (1981; see also Seiderer et al. 1982). Apart from the work of Elyakova (1972) on cellulases and chitinases in Halocyntia aurantium there is little information on digestive enzymes in ascidians.

The activity of protease, chitinase, $\alpha$-amylase, 

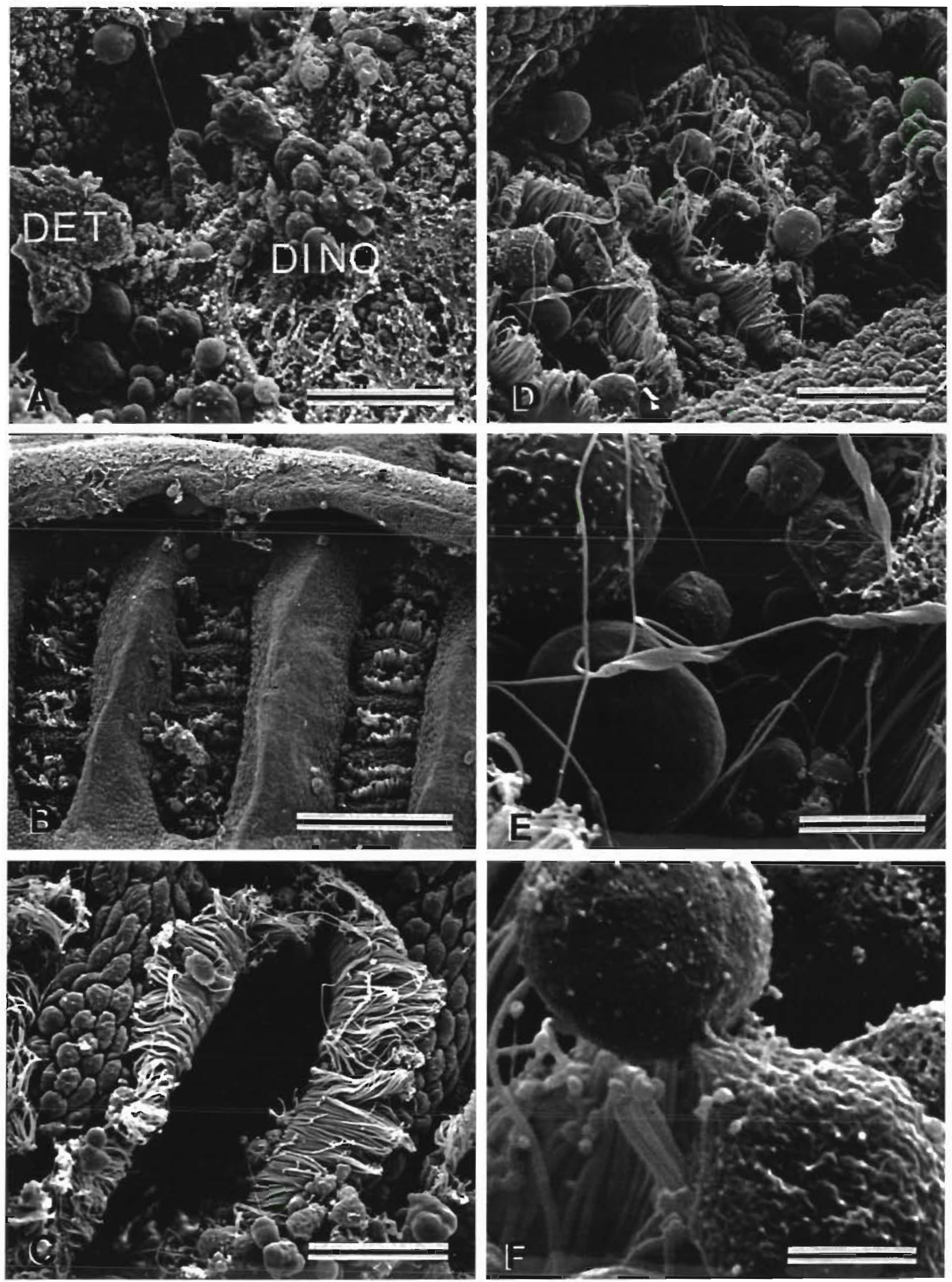

Fig. 1. Pyura stolonifera. Scanning electron micrographs of the pharyngeal basket of specimens freshly collected from the subtidal zone at Oudekraal on the west coast of the Cape Peninsula, South Africa. (A) Wide variety of particles associated with the inhalant siphon. (B, C) Successive enlargements of the pharyngeal basket and ciliated pharyngeal slits. (D, F) Detals of the 3 to $5 \mu \mathrm{m}$ diameter cells which formed a dominant component of the food supply which was being filtered by the ascidians under natural conditions at the time of collection. DET: detritus; DINO: dinoflagellates. Scale bars: A, $20 \mu \mathrm{m} ; \mathrm{B}, 100 \mu \mathrm{m} ; \mathrm{C}, 20 \mu \mathrm{m} ; \mathrm{D}, 20 \mu \mathrm{m}$; E, 

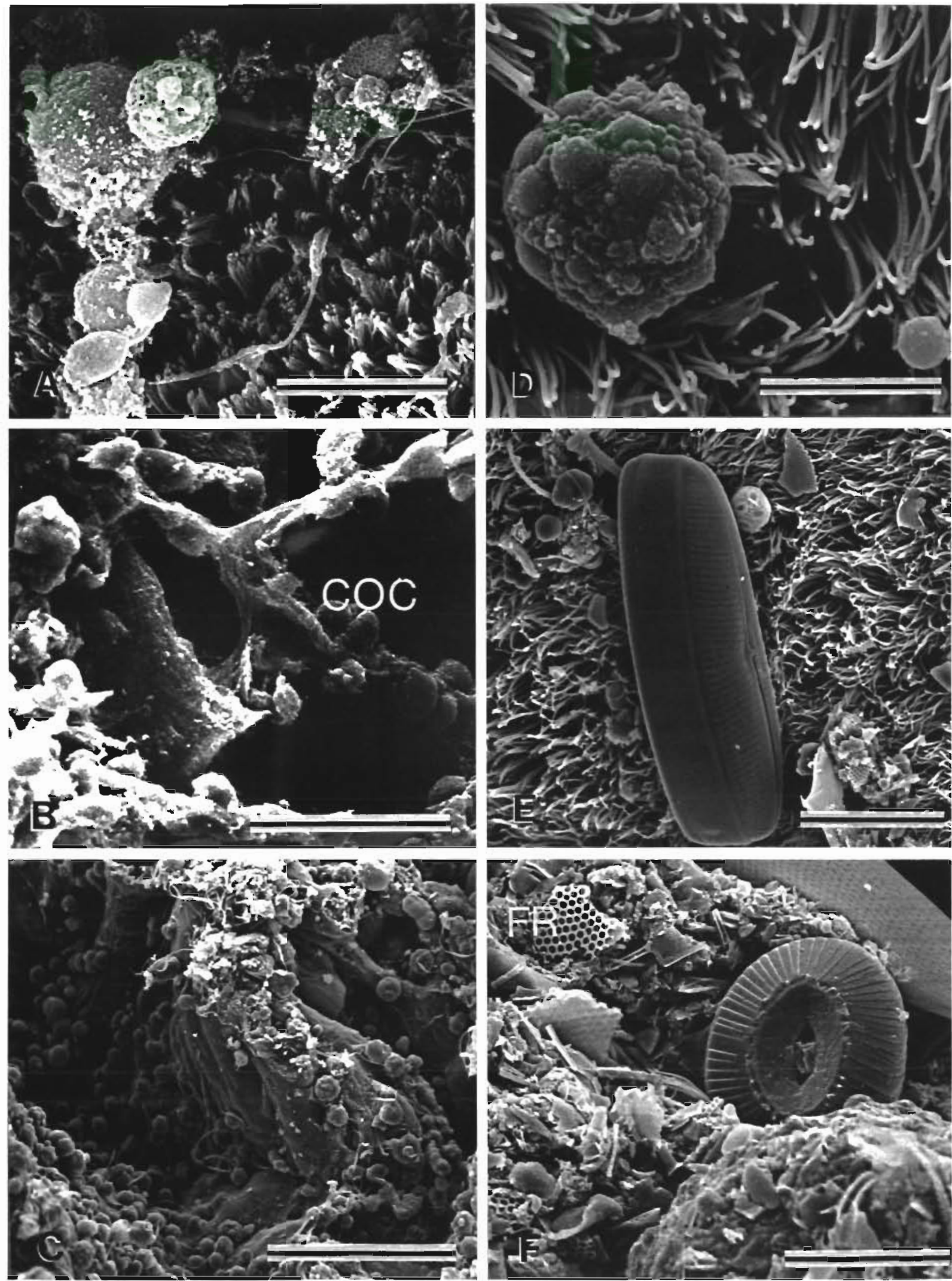

Fig. 2. Pyura stolonifera. Scanning electron micrographs of the endostyle, stomach and hind gut contents of specimens freshly collected from the subtidal zone at Oudekraal on the west coast of the Cape Peninsula, South Africa. (A, B) Surface of the endostyle; note the occurrence of coccoid cells associated with mucilage strands in the endostyle. (C, D) Details of cells in the stomach: note the partial lysis of the 3 to $5 \mu \mathrm{m}$ cells noted in the pharyngeal basket. (E) Diatom cell in the hind gut showing little evidence of digestion. (F) Diatom frustules and other undigested refractory material in the faeces. COC: coccoid cells; FR: diatom frustules. Scale bars: A, $10 \mu \mathrm{m} ; \mathrm{B}, 20 \mu \mathrm{m} ; \mathrm{C}, 50 \mu \mathrm{m} ; \mathrm{D}, 5 \mu \mathrm{m} ; \mathrm{E}, 20 \mu \mathrm{m} ; \mathrm{F}, 10 \mu \mathrm{m}$ 
laminarinase and cellulase in extracts of the endostyle and gut of Pyura stolonifera is summarised in Table 1. The protein content of the crude extracts is also shown. Protease activity is expressed as $\mu \mathrm{g}$ equivalents of proteinase-K (Merck) per $\mathrm{mg}$ protein following incubation for up to $1 \mathrm{~h}$ at $24^{\circ} \mathrm{C}$. Chitinase was expressed as $\mu \mathrm{g}$ NAG per mg protein following incubation in the presence of toluene for up to $120 \mathrm{~h}$. All the carbohydrases were expressed as $\mathrm{mg}$ maltose ( $\mathrm{mg}$ protein) ${ }^{-1}$ following incubation at $24^{\circ} \mathrm{C}$ for up to $0.5 \mathrm{~h}$ in the case of the $\alpha$ amylase and laminarinase, and for $43 \mathrm{~h}$ in the case of the cellulase. All results were then expressed as a rate of activity per hour at $24^{\circ} \mathrm{C}$. Carbohydrase activity was also expressed in terms of the carbon released $(\mathrm{mg}$ protein $)^{-1} \mathrm{~h}^{-1}$.

The results summarised in Table 1 show that enzyme activity in the endostyle is negligible. Both protease and chitinase activity was recorded in the gut contents. Very little cellulase activity occurred in the gut but both laminarinase and to a major extent $\alpha$-amylase were of importance. This indicates that carbohydrates occurring as storage products in phytoplankton (Darley 1977. Myklestad 1978) are likely to be of more significance in the diet of Pyura stolonifera than the refractory particulate components in the water column.

\section{Characterisation of the gut microflora}

Although bacteria are sparse in the gut of Pyura stolonifera (Figs. 1 and 2), gut microflora have been widely implicated both in the digestion of complex carbohydrates and in nitrogen assimilation in invertebrates (Mann 1982).

The utilisation of a variety of substrates by 8 bacterial isolates from the endostyle, 2 isolates from the inhalant siphon, 4 from the gut contents and 1 from the faeces is summarised in Table 2 . These were assayed by a combination of standard microbiological tests (Davis 1985) and A.P.I tests (A.P.I System S.A., La Balme Les Grottes, 38390 Montalieu, Vercieu, France).

Cultures 1 to 5 from the endostyle were evidently similar to one another while Cultures 6 to 8 were also similar to one another. This indicates that the microflora of the endostyle is dominated by 2 main components. Liquid assays of chitinase and laminarinase allowed us to calculate the specific activities of these 2 enzymes. Although these amounted to $0.10 \mu \mathrm{g} \mathrm{NAG}$ (mg bacterial protein) ${ }^{-1} \mathrm{~h}^{-1}$ for the chitinase and $5.0 \mu \mathrm{g}$ maltose (mg bacterial protein) ${ }^{-1} \mathrm{~h}^{-\mathbf{i}}$ in the case of the laminarinase, the low densities of bacteria observed under the scanning electron microscope (Fig. 2B) suggests that chitinases and laminarinases of bacterial origin probably make an insignificant contribution to the digestion of these substrates in the endostyle. Most of the assays for other complex substrates were negative (Table 2), including phenyl acetate, indicating an inability to use long chain fatty acids, although almost all isolates were capable of utilisation of nitrogenous substrates.

Although the colony morphology of isolates of bacteria from the gut and faeces of Pyura stolonifera was

Table 1. Pyura stolonifera. Activity of protease ( $\mu \mathrm{g}$ equivalents of proteinase-K $\left.(\mathrm{mg} \text { protein) })^{-1}\right)$, chitinase $\left(\mu \mathrm{g}\right.$ NAG (mg protein) $\left.{ }^{-1}\right)$, $\alpha$-amylase, laminarinase and cellulase in extracts of the endostyle and gut contents of specimens incubated at $24{ }^{\circ} \mathrm{C}$ for various time intervals. Protease: $T_{1}=30 \mathrm{~min} ; T_{2}=60 \mathrm{~min}$. Chitinase: $T_{1}=48 \mathrm{~h} ; T_{2}=120 \mathrm{~h}, \alpha$-amylase and laminarinase: $T_{1}=10 \mathrm{~min}, T_{2}=$ $30 \mathrm{~min}$. Cellulase: $\mathrm{T}_{1}=48 \mathrm{~h}$. Activity of all the carbohydrases are expressed as $\mu \mathrm{g}$ maltose $\left(\mathrm{mg}\right.$ protein) ${ }^{-1}$ Final column shows rate of activity $h^{=1}$ and in the case of the carbohydrases has been converted into equivalent carbon release $\mathrm{h}^{-1}$ Total carbon released (mg protein) $)^{-1} \mathrm{~h}^{-1}$ by carbohydrase activity in the endostyle and gut is also shown

\begin{tabular}{|c|c|c|c|c|c|c|c|}
\hline & \multicolumn{3}{|c|}{ Endostyle } & \multicolumn{3}{|c|}{ Gut contents } & \multirow{2}{*}{$\begin{array}{l}\text { Rate end product } \\
\text { release } \mathrm{h}^{-1}\end{array}$} \\
\hline $\begin{array}{l}\text { Protein in extract } \\
\left(\text { mg ml }{ }^{-1}\right)\end{array}$ & & 2.40 & & & 0.60 & & \\
\hline Enzymes & $T_{0}$ & $\mathrm{~T}_{1}$ & $\mathrm{~T}_{2}$ & $T_{0}$ & $T_{1}$ & $\mathrm{~T}_{2}$ & \\
\hline Protease & 0.200 & 0.208 & 0.250 & 1.117 & 1.167 & 1.833 & $0.766 \mu \mathrm{gg}(\mathrm{mg} \text { protein })^{-1} \mathrm{~h}^{-1}$ \\
\hline Chitinase & 0.0 & 0.0 & 0.0 & 0.0 & 5.9 & 16.5 & $0.14 \mu \mathrm{g} \mathrm{NAG}$ (mg protein) $)^{-1} h^{-1}$ \\
\hline$\alpha$-amylase & 0.018 & 0.018 & 0.016 & 0.003 & 2.123 & 4.348 & $\begin{array}{l}8.690 \mathrm{mg} \text { maltose (mg protein })^{-1} \mathrm{~h}^{-1} \\
\left(=3.476 \mathrm{mgC}(\mathrm{mg} \text { protein) })^{-1} \mathrm{~h}^{-1}\right)\end{array}$ \\
\hline Laminarinase & 0.074 & 0.075 & 0.068 & 0.171 & 0.221 & 0.478 & $\begin{array}{l}0.613 \mathrm{mg} \text { maltose (mg protein) } \\
\left.(=0.245 \mathrm{mgC} \text { (mg protein })^{-1} \mathrm{~h}^{-1}\right)\end{array}$ \\
\hline \multirow[t]{2}{*}{ Cellulase } & 0.063 & 0.092 & - & 0.096 & 0.223 & - & $\begin{array}{l}0.004 \mathrm{mg} \text { maltose (mg protein })^{-1} \mathrm{~h}^{-1} \\
\left.\{=0.0016 \mathrm{mgC} \text { (mg protein) })^{-1} \mathrm{~h}^{-1}\right\}\end{array}$ \\
\hline & \multicolumn{6}{|c|}{ Total carbohydrase activity } & $\begin{array}{l}9.306 \mathrm{mg} \text { maltose (mg protein })^{-1} h^{-1} \\
\left.(=3.722 \mathrm{mgC} \text { (mg protein) })^{-1} h^{-1}\right)\end{array}$ \\
\hline
\end{tabular}


very different from those isolated from the endostyle, their substrate specificity was generally similar to the endostyle bacteria. Liquid assays of the gut microflora yielded values of ca $0.1 \mu \mathrm{g} \mathrm{NAG}$ (mg bacterial protein) $)^{-1} h^{-1}$ for the chitinase and 3 to $4 \mu \mathrm{g}$ maltose (mg bacterial protein $)^{-1}$ for the laminarinase, values which are similar to those for the endostyle isolates. Because of the low density of bacteria, and the relatively low specific activity of the bacterial enzymes compared with those originating from the ascidian itself (Table 1), bacteria seem unlikely to make a significant contribution to the exploitation of polysaccharides in the gut of P. stolonifera.

\section{DISCUSSION}

Because we have measured the carbohydrase activity of the principal enzymes in the gut of Pyura stolonifera, it becomes possible to estimate the extent to which carbon release could meet the carbon demands of the ascidian when food supply is not limiting.

Table 3 shows the dry weight, gut volume and total gut protein in a series of 6 individuals. The oxygen consumption and carbon equivalent can be estimated from the data of Klumpp (1984), whilst the total rate of carbon release by enzyme activity is the product of the carbohydrase activity (from Table 1) and the protein content of the entire gut. Finally, the 'net gain' or amount of carbon available to support growth and reproduction is given by the difference between total carbon released by enzyme activity and carbon used in respiration.

Inspection of Table 3 shows that the average respiratory carbon demand for the 6 Pyura stolonifera amounted to $0.158 \mathrm{mg} \mathrm{h}^{-1}\left(=0.292 \mathrm{ml} \mathrm{O}_{2} \mathrm{~h}^{-1}\right)$. The total carbon released from carbohydrase activity by the entire gut was as much as $3.701 \mathrm{mg} \mathrm{C} \mathrm{h}^{-1}$. Thus respiratory demands in this ascidian amount to only $4.27 \%$ of the potential carbon released, yielding a potential carbon gain of $3.543 \mathrm{mg} \mathrm{Ch}^{-1}$ or $95.7 \%$ of the carbon potentially available for assimilation. These conclusions are in general agreement with those of Klumpp (1984) who estimated that at a density of $60 \times$ $10^{6}$ cells $1^{-1}$ of the alga Dunaliella primolecta, a $P$. stolonifera of $1 \mathrm{~g}$ tissue weight had an assimilated ratio of $48 \mathrm{~J} \mathrm{~h}^{-1}$ and a respiratory cost of $2.8 \mathrm{~J} \mathrm{~h}^{-1}$. This gives respiratory costs of $5.83 \%$ of the absorbed ration, and a net energy gain of $94.17 \%$ available to support growth and reproduction. The evidence suggests, therefore, that unlike most molluscs where respiratory costs represent as much as 25 to $50 \%$ of the ingested ration (Bayne \& Newell 1983), there is a relatively large carbon flow available as 'scope for growth'. It seems likely

Table 2. Substrates utilised by isolates of bacteria from the endostyle (Nos. 1 to 8), inhalant siphon (Nos. 9 \& 10), gut contents (Nos. 11 to 14) and faeces (No. 15) of Pyura stolonifera. a: Plate assays, b: liquid assays, c: A.P.I. tests (non-enteric); + : utilisation of substrate, - : non-utilisation of substrate, \pm : variable utilisation of substrate, 0 : no result

\begin{tabular}{|c|c|c|c|c|c|c|c|c|c|c|c|c|c|c|c|c|}
\hline \multirow[t]{2}{*}{ Substrate } & \multirow[t]{2}{*}{ Assay } & \multicolumn{8}{|c|}{ Endostyle } & \multicolumn{2}{|c|}{$\begin{array}{l}\text { Inhalant } \\
\text { siphon }\end{array}$} & \multicolumn{4}{|c|}{ Gut contents } & \multirow{2}{*}{$\begin{array}{c}\text { Faeces } \\
15\end{array}$} \\
\hline & & 1 & 2 & 3 & 4 & 5 & 6 & 7 & 8 & 9 & 10 & 11 & 12 & 13 & 14 & \\
\hline$\beta$ Glucose & c & + & + & + & + & \pm & + & \pm & \pm & - & \pm & + & + & + & + & + \\
\hline$\beta$ Galactose & c & + & + & - & + & \pm & + & + & \pm & + & + & + & + & + & + & + \\
\hline Glucose (Ferm.) & c & - & - & - & - & - & + & + & + & - & - & - & - & - & - & - \\
\hline Arabinose & c & - & - & - & - & - & + & + & + & - & - & - & - & - & - & - \\
\hline Mannose & c & - & - & - & - & - & - & + & + & - & - & - & - & - & - & - \\
\hline Mannitol & c & - & - & - & - & - & - & - & - & - & - & - & - & - & - & - \\
\hline NAG & c & - & - & - & - & - & - & - & - & - & - & - & - & - & - & - \\
\hline Maltose & c & - & - & - & - & - & + & + & + & - & + & - & - & - & - & - \\
\hline Gluconate & c & - & - & - & - & + & + & + & + & - & + & - & - & - & - & - \\
\hline Chitin & $a b$ & - & + & + & + & 0 & - & - & - & - & - & + & - & + & - & - \\
\hline Agar & $\mathrm{a}$ & - & + & - & - & 0 & 0 & 0 & 0 & - & - & - & + & - & - & - \\
\hline Starch & a & + & + & - & - & + & + & - & + & - & - & - & - & - & - & - \\
\hline Laminarin & $a b$ & + & + & + & + & 0 & + & + & + & + & + & + & - & + & + & - \\
\hline Alginate & a & + & + & - & - & + & + & - & - & - & - & - & - & - & - & - \\
\hline $\mathrm{CMC}$ & a & - & - & - & - & - & - & - & - & - & - & - & - & - & - & - \\
\hline Nitrates & c & + & + & - & + & + & + & + & + & + & + & + & + & + & + & + \\
\hline Skim milk & a & + & \pm & + & \pm & - & + & - & + & + & + & - & - & - & - & - \\
\hline Gelatin & a & + & + & \pm & \pm & 0 & + & + & + & - & + & - & \pm & - & - & - \\
\hline Target bacteria & a & - & + & - & - & + & - & - & - & + & - & - & + & - & - & - \\
\hline Phenyl acetate & c & - & - & - & - & - & - & - & - & - & - & - & - & - & - & - \\
\hline
\end{tabular}


that much of this is used in the formation of the massive test structure which in $P$. stolonifera is many times the weight of the ascidian itself.

Klumpp (1984) found, in addition, that in the presence of natural seston, comprising a high proportion of detritus with varying amounts of silt, the absorption efficiency fell from $75 \%$ in the presence of Dunaliella primolecta to ca $34 \%$, so that the energy gain was less on seston than when algal cells were used as a food resource.

Our observations suggest that this fall in absorption efficiency in the presence of natural seston compared with that with Dunaliella primolecta cells is because Pyura stolonifera does not posses the necessary digestive enzymes to exploit the particulate detrital component. The ascidian does, however, appear to be capable of a degree of selection of the algal components to which its digestive enzymes are suited and many concentrate algal cells ingested from the mixed resource of particulate detritus, silt and phytoplankton in the water column. The relatively high specific activity of the carbohydrases allows a large energetic gain in the presence of algal cells. $P$. stolonifera thus appears to be well-adapted for exploitation of the episodic phytoplankton availability which characterises the kelp bed system (Wulff \& Field 1983).

The digestive enzymes of the dominant kelp bed mussel Choromytilus meridionalis also comprise mainly $\alpha$-amylase (Sejderer et al. 1982) and mussels also show a much lower absorption efficiency of ca $40 \%$ in the presence of kelp detritus, compared with values as high as $75 \%$ when fed with algal cells (Griffiths 1980). This suggests that these mussels may also primarily exploit phytoplankton, rather than the more refractory components of the seston. Much of the particulate material which dominates the water column in kelp beds on the west coast of the Cape Peninsula may thus enter the microheterotrophic decomposer pathway, rather than form a nutritional resource which is exploited directly by the filter-feeding community.

Acknowledgements. L. J. S. was supported by funds from the FRD Main Research Support Programme Team Grant award to Profs. G. M. Branch and J. G. Field and Dr C. L. Griffiths. R. C. N. received travelfunds from the South African National Committee for Oceanographic Research (SANCOR) to the Benguela Ecology Programme. Thanks go to Rick and Robyn Harding for collection of the animals and for endless patience, to Klaus Schultes of the Electron Microscope Unit, U.C.T., and to Sandy Tolosana for assistance in preparation of the manuscript.

\section{LITERATURE CITED}

Barnes, R. D. (1974). Phylum Chordata. In: Invertebrate zoology. W. B. Saunders \& Co., p. 807-817

Bayne, B. L., Newell, R. C. (1983). Physiological energetics of marine molluscs. The Mollusca, Vol. 4. Physiology, Part 1. Academic Press, London, p. 407-51.5

Carpenter, E. J., Culliney, J. L. (1975). Nitrogen fixation in marine shipworms. Science 187: 551-552

Darley, W. M. (1977). Biochemical composition. In: Werner, D. (ed.) The Biology of the diatoms. Botanical monographs, Vol. 13. Blackwell Scientific Publications, Oxford, p. $198-223$

Davis, C. L. (1985). Physiological and ecological studies of mannitol utilizing marine bacteria. Ph.D. thesis, Univ. of Cape Town, Rondebosch

Elyakova, L. A. (1972). Distribution of cellulases and chitinases in marine invertebrates. Comp. Biochem. Physiol. 43B: $67-70$

Elyakova, L. A., Shevchenko, N. M., Avaeva, S. M. (1981). A comparative study of carbohydrase activities in marine invertebrates. Comp. Biochem. Physiol. 67B: 905-908

Field, J. G., Jarman, N. G., Dieckmann, G. S., Griffiths, C. L., Velimirov, B., Zoutendyk, P. (1977). Sun, waves, seaweed and lobsters: the dynamics of a west coast kelp bed. S.Afr. J. Sci. 73: 7-10

Table 3. Pyura stolonifera. Body weight (dry tissue, g) gut volume (ml) and gut protein content (mg) for 6 specimens. Oxygen consumption values and equivalent carbon demand $\left({ }^{R} / 1.85\right)$ are estimated from data in Klumpp (1984). Since the carbon released from digestive enzymes in the gut was $3.722 \mathrm{mgC}$ (mg protein) $)^{-1} \mathrm{~h}^{-1}$ (see Table 1), the total carbon release from the gut contents was obtained from the gut protein content $\times 3.722$. 'Net gain' of carbon potentialiy available to support growth and reproduction is given in the final column (carbon release-respiratory carbon demand)

\begin{tabular}{|c|c|c|c|c|c|c|c|}
\hline $\begin{array}{l}\text { Animal } \\
\text { No. }\end{array}$ & $\begin{array}{c}\text { Dry weight } \\
(g)\end{array}$ & $\begin{array}{l}\text { Gut volume } \\
\qquad(\mathrm{ml})\end{array}$ & $\begin{array}{c}\text { total gut } \\
\text { protein }(\mathrm{mg}) \\
\operatorname{Pr}\end{array}$ & $\begin{array}{c}\mathrm{O}_{2} \text { uptake } \\
\left(\mathrm{m} . \mathrm{h} \mathrm{h}^{-1}\right) \\
\mathrm{R}_{O}\end{array}$ & $\begin{array}{c}\text { Respiratory } \\
\text { carbon demand } \\
\left(\mathrm{R}_{\mathrm{O}} / 1.85 \mathrm{mg} \mathrm{h}^{-1}\right) \\
\mathrm{R}_{\mathrm{C}}\end{array}$ & $\begin{array}{c}\text { Carbon released } \\
\text { by gut enzymes } \\
(\operatorname{Pr} \times 3.722) \\
\text { C }\end{array}$ & $\begin{array}{c}\text { Net gain } \\
\mathrm{C}-\mathrm{R}_{\mathrm{C}} \\
\left(\mathrm{mgCh} \mathrm{h}^{-1}\right)\end{array}$ \\
\hline 1 & 1.89 & 0.165 & 0.594 & 0.20 & 0.108 & 2.211 & 2103 \\
\hline 2 & 1.98 & 0.222 & 0.799 & 0.20 & 0.108 & 2.974 & 2.866 \\
\hline 3 & 3.78 & 0.212 & 0.763 & 0.40 & 0.216 & 2.840 & 2.624 \\
\hline 4 & 2.26 & 0.198 & 0.713 & 0.30 & 0.162 & 2.654 & 2.492 \\
\hline 5 & 3.57 & 0.408 & 1.469 & 0.40 & 0.216 & 5.468 & 5.252 \\
\hline 6 & 2.42 & 0.452 & 1.627 & 0.25 & 0.135 & 6.056 & 5.921 \\
\hline Mean & 2.65 & 0.276 & 0.994 & 0.29 & 0.158 & 3.701 & 3.543 \\
\hline $\mathrm{SD}$ & 0.82 & 0.122 & 0437 & 0.09 & 0.050 & 1.628 & 1.616 \\
\hline
\end{tabular}


Field, J. G., Griffiths, C. L., Linlezy, E. A. S., Carter, R. A., Zoutendyk, P. (1980). Upwelling in a nearshore marine ecusystem and its biological implications. Estuar coast. mar. Sci. 11: 133-150

Fong, W. C., Mann, K. H. (1980). Role of gut flora in the transfer of amino acids through a marine food chain. Can. J. Fish. Aquat. Sci. 37: 88-96

Griffiths, R. J. (1980). Natural food availability and assimilation in the bivalve Choromytilus meridionalis. Mar. Ecol. Prog. Ser 3: 151-156

Hidaka, T (1953). On the cellulose decomposing bacteria found in the digestive organs of Teredo (Teredo navalis sp.). Suisan Gakuba Kiyo 3: 149-157

Jacober, L. F., Rice, C., Rand, A. G., Jr (1980). Characterization of the carbohydrate degrading enzymes in the surf clam crystalline style. J. Food Sci. 45: 381-385

Klumpp, D. W. (1984). Nutritional ecology of the ascidian Pyura stolonifera: influence of body size, food quantity and quality on filter-feeding, respiration, assimilation efficiency and energy balance. Mar. Ecol. Prog. Ser. 19: 269-284

Koop, K., Carter, R. A., Newell, R. C. (1982). Mannitol-fermenting bacteria as evidence for export form kelp beds. Limnol. Oceanogr. 27: 950-954

Kristensen, J. H. (1972). Carbohydrases of some marine invertebrates with notes on their food and on the natural occurrence of the carbohydrates studied. Mar. Biol. 14: $130-142$

Lasker, R., Giese, A. C. (1954). Nutrition of the sea urchin Strongylocentrotus purpuratus. Biol. Bull. mar biol. Lab., Woods Hole 106: 328-340

Long, S., Mothibeli, M. A., Robb, F. T., Woods, D. R. (1981). Regulation of extracellular alkaline protease activity by histidine in a collagenolytic Vibrio alginolyticus strain. J. gen Microbiol. 127: 193-199

Lowry, O. H., Roseborough, N. J., Farr, A. L., Randall, R. N. (1951). Protein measurements with the folin phenol reagents. J. biol Chem. 193: 265-275

Mann, K. H. (1982). Ecology of coastal waters - a system approach. Studies in ecology, Vol. 8. Blackwell Scientific Publications, Oxford

Millar, R. H. (1960). Ascidiacea. 'Discovery' Rep. 30: 1-160

Monreal, J., Reese, E. T (1969). The chitinase of Serratia marcescens. Can. J. Microbiol 115: 689-696

Morita, R. Y (1980). Microbial contributions to the various marine trophic levels. In: Resistencia a los antibioticos y Microbiologia marina. Proc. VI National Microbiology Congress (1977), Sandiago de Compestela (Spain). Published as Technical Paper No. 4096. Oregon Agricultural Experimental Station

Myklestad, S. (1978). $\beta$-1,3-glucans in diatoms and brown seaweeds. In: Hellebust, J. A., Craigie, J. C. (eds.) Handbook of phycological methods, Vol. 2, Physiological and biochemical methods. Cambridge University Press, Cambridge, p. 133-141

Nelson, $M$. (1952). A photometric adaptation of the Somogyi method for the determination of glucose. J. biol. Chem. 195: 375-380

Newell, R. C., Field, J. G. (1983a). The contribution of bacteria and detritus to carbon and nitrogen flow in a benthic community. Mar. Biol. Lett. 4: 23-36

Newell, R. C., Field, J. G. (1983b). Relative flux of carbon and nitrogen in a kelp-dominated system. Mar Biol. Lett. 4: 249-257

Okutani, K. (1966). Studies of chitinolytic systems in the digestive tracts of Lateolabrax japonicus. Bull. Misaki mar Biol. Inst. Kyoto Univ. 10: 1-47

Prieur, D. (1981). Experimental studics of trophic relationships between marine bacteria and bivalve molluscs. Kieler Meeresforsch., Sonderh. 5: 376-383

Prieur, D. (1982). La microflore du tractus digestif des bivalves marins: étude experimentale chez la moule, Mytilus edulis. Malacologia 22: 653-658

Prim, P., Lawrence, J. M. (1975). Utilization of marine plants and their constituents by bacteria isolated from the gut of Echinoids (Echinodermata). Mar. Biol. 33: 167-173

Reichenbach, H., Dworkin, M. (1981). The order Myxobacteriales. In: Starr, M. P., Stolp, M., Truper, H. G., Balows, A. Schlegel, H. C. (eds.) The prokaryotes, Vol. 1. SpringerVerlag, Berlin, p. 360-376

Reimerdes, E. H., Klostermeyer, H. (1976). Determination of proteolytic activities on casein substrates. In: Colowick, S. P., Kaplan, N. O. (eds.) Methods in enzymology, Vol. XLV Proteolytic enzymes, Part B. Academic Press, New York, p. 26-28

Reissig, J. L., Strominger, J. L., Leloir, L. F. (1955). A modified colorimetric method for the estimation of $\mathrm{N}$-acetylamino sugars. J. biol. Chem. 217.959-966

Seiderer, L. J., Newell, R. C., Cook, P. A. (1982). Quantitative significance of style enzymes from two marine mussels (Choromytilus meridionalis Krauss and Perna perna Linnaeus) in relation to diet. Mar. Biol. Lett. 3: 257-271

Seiderer, L. J., Davis, C. L., Robb, F. T., Newell, R. C. (1984). Utilisation of bacteria as nitrogen resource by kelp-bed mussel Choromytilus meridionalis. Mar Ecol. Prog. Ser. 15: 109-116

Seiderer, L. J., Newell, R. C., Schultes, K., Robb, F. T., Turley, C. M. (1987). Novel bacteriolytic activity associated with the style microflora of the mussel Mytilus edulis (L.). J. exp. mar. Biol. Ecol. 110: 213-224

Stuart, V., Lucas, M. I., Newell, R. C. (1981). Heterotrophic utilisation of particulate matter from the kelp Laminaria pallida. Mar Ecol. Prog. Ser. 4: 337-348

Stuart, V., Klumpp, D. W. (1984). Evidence for food resource partitioning by kelp-bed filter-feeders. Mar Ecol. Prog. Ser 16: $27-37$

Velimirov, B., Field, J. G., Griffiths, C. L., Zoutendyk, P. (1977). The ecology of kelp bed communities in the Benguela upwelling system. Analysis of biomass and spatial distribution. Helgoländer wiss. Meeresunters. 30: 495-518

Wainwright, P. F., Mann, K. H. (1982). Effect of antimicrobial substances on the ability of the mysid shrimp Mysis stenolepis to digest cellulose. Mar. Ecol. Prog. Ser 7: 309-313

Wulff, F. V., Field, J. G. (1983). The importance of different trophic pathways in a nearshore benthic community under upwelling and downwelling conditions. Mar Ecol. Prog. Ser 12: $217-228$ 